\title{
MANFAAT YOGHURT BAGI PENDERITA DIABETES MELLITUS
}

\author{
Zainal Arilin Nang Agus ${ }^{\prime}$
}

\section{INTISARI}

Penelitian ini bertujuan untuk mengetahui manfat yoghurt bagi penderita Diabetes Mellitus (DM). Dengan rancangan eksperimen pretest-posttest, 10 penderita DM diberi 150 g yoghurt setiap 2 hari selama 1 bulan. Secara anamnesis didapatkan hasil bahwa penderita merasa kondisi badannya lebih segar. Hasil pemeriksaan fisik dan laboratorik didapatkan bahwa berat badan dan kadar $\mathrm{Hb}$ naik bermakna $(\mathrm{P}<0,05)$, sedangkan kadar glukosa darah menurun tetapi tidak bermakna $(P>0,05)$.

(Kata kunci: Diabetes, Pengobatan diabetes, Yoghurt.)

Buletin Peternukun 19: 191-199, 1995

\section{THE ADVAN'TAGE OF YOGHURT FOR DIABETIC PATIENT}

\begin{abstract}
This study was conducted to determine the advantage of yoghurt for diabetic patient. The experimental design for this study was completely randomized using diabetic patients as subject. Ten diabetic patients were given $150 \mathrm{~g}$ yoghurt every 2 days for a month. The result showed that the patients fell more better, the body weight and hemoglobin concentration increased significantly $(P<0,05)$, whereas glucose concentration decreased but not-significant $(\mathbb{P}>0,05)$. It was concluded that yoghurt could increase the nutritional status without along with increase of blood glucose concentration.
\end{abstract}

(Keywords: Diabetic, Diabetic therapy, Yoghurt.)

Fakultas Kedokteran UGM Yogyakarta 


\section{Pendahuluan}

Diabetes Mellitus (DM) adalah penyakit kronis yang pada fase awal ditandai olelı adanya gangguan metabolisme karbohidrat dan pada fase lanjut akan juga lerjadi gangguan metabolisme lemak dan protein (Talwar, 1980; WHO, 1985; Stryer, 1988). Sebagian ahli berpendapat bahwa DM bukan merupakan penyakit dalam artian klasik, tetapi merupakan suatu kelainan metabolik dengan berbagai tipe (Martin et al., 1989; Asdie, 1990). Gangguan metabolik itu berpangkal pada defisiensi insulin karena kerusakan sel- $\beta$ pulau Langerhans akibat faktor genetis atau proses autoimun atau faktor lain. Akibat defisiensi insulin, glukosa darah tidak dapat masuk ke dalam sel, disamping itu glikogenesis menurun sehingga terjadi hiperglikemia. Bila kadar glukosa di dalam sel rendah maka proses pembentukan energi melalui oksidasi glukosa hanya sedikit, sebagai kompensasinya maka oksidasi asam lemak dan asam amino meningkat. Asam lemak dan asam amino yang dioksidasi tersebut berasal dari asam lemak dan protein tubuh (protein endogenous). Bila kejadian ini berlangsung dalam waktu relatif lama maka berat badan penderita menurun dengan cepat dan Japat terjadi ketoasidosis. Tingginya mortalitas DM, umumnya diakibatkan oleh komplikasi malnutrisi, nefritis dan ketoasidosis (Devlin, 1982; Asdie, 1987).

Kadar glukosa darah dipengaruli oleh diit dan proses metabolisme. Pada keadaan normal, sesaat setelah makan kadar glukosa darah naik mencapai $130-180 \mathrm{mg} \%$, tetapi 2 jam kemudian turun sampai seperti kadar pada waktu puasa yaitu $80-100 \mathrm{mg} \%$ (Talwar, 1980). Diagnosis DM ditegakkan bila kadar glukosa darah pada waktu puasa di atas $140 \mathrm{mg} \%$ dan di atas $200 \mathrm{mg} \%$ setelah 2 jam diberi $75 \mathrm{~g}$ glukosa peroral atau post parandial (WHO, 1985). Kenaikan kadar glukosa darah ini sesuai dengan derajat defisiensi insulin (Devlin, 1982; Tiezt, 1986).

Dalam terapi DM ada 2 aspek penting yang perlu diperhatikan; pertama memperbaiki status nutrisi, ke dua pengendalian metabolik dan mencegah timbulnya komplikasi (WHO, 1985). Banyak jenis makanan yang harus dipilih dan diatur distribusi komposisinya oleh penderita DM, terutana makanan sumber glukosa.

Tindakan memperbaiki nutrisi dan mencegah komplikasi pada DM tentunya dengan pemberian makanan bergizi tinggi dan berenergi rendah, dapat disertai obat antihiperglikemia. Salah satu jenis bahan makanan yang bergizi tinggi telapi berenergi rendah adalah yoghurt. Disamping itu yoghurt telah mulai disukai masyarakat.

Berdasarkan analisis di atas timbul pertanyaan apakah yoghurt dapat diterima sebagai makanan substitusi pada penderita DM dan apakah konsumsi yoghurt sebanyak $150 \mathrm{~g}$ setiap hari selama 1 bulan pada penderita DM tersebut dapat meningkatkan status gizi agar tetap baik tanpa diikuti kenaikan kadar glukosa darah.

\section{Materi dan Metoda}

Subjek penelitian adalah penderita DM, tidak ada komplikasi, berusia antara 40 - 55 tahun dan bersedia secara sukarela menjadi subjek dengan menandatangani inform concern. Sebelum diberi perlakuan, subjek diperiksa (pre-test) secara diagnosis fisik dan dilakukan tes minum $150 \mathrm{~g}$ yoghurt. Sehelum tes minum yoghurt, subjek berpuasa 10 jam, mulai jam 10.00 malam lalu pada jam 08.00 pagi hari diambil darah, setelah itu diberi minum 150 g yoghurt; setelah 30 menit dan 120 menit dari minum yoghurt darah diambil lagi. Jumlalı darah yang diambil sebanyak $0,5 \mathrm{ml}$ dar

dim

$\mathrm{Nal}$

den

dan

Sia

yog

Bile

ber:

yog

itu

yan

sub

Yos

dipe

pen

den;

mer

yog

dica

pen

dihi

mak

con

sebe

baha

buk:

dike

(198

subj,

dan

ditar

pend

kom

oran

dalaı

digu:

antid 
dari vena mediana kubiti. Kemudian darah dimasukan ke dalam botol berisi antikoagulan $\mathrm{NaF}$, kemudian ditentukan kadar glukosanya dengan metode glukosa oksidase (Tiezt, 1986) dan ditentukan juga kadar $\mathrm{Hb}$ dengan metode Sianmet (Tiezt, 1986). Mulai dari saat minum yoghurt sampai 6 jam diamati kelulıan perut. Bila tidak ada keluhan perut, mulai hari berikutnya, subjek diberi minum $150 \mathrm{~g}$ yoghurt setiap 2 hari selama 1 bulan, setelah itu dilakukan pemeriksan ulang (post-test) yang prosedurnya sama seperti pada pre-test. Yoghurt yang diberikan kepada subjek, dibeli dari sebuah toko di Yogyakarta, selalu diambil yang terbaru dan diperiksa komposisinya. Selama perlakuan, pemberian oral antidiabetik diteruskan sesuai dengan kondisinya dan diit dianjurkan dengan memperhitungkan masukan energi dari yoghurt yang diberikan. Diit diamati dan dicatat selama 1 minggu pada awal dan aklir penelitian. Total masukan energi dan zat gizi dihitung reratanya berdasarkan berat bahan makanan yang dimakan, dibandingkan dengan contoh bahan makanan yang telah ditimbang sebelumnya. Perhitungan kandungan zat gizi bahan makanan tersebut ditentukan menurut buku daftar komposisi bahan makanan yang dikeluarkan oleh Direktorat Gizi Depkes RI (1981).

Selama penelitian, pada setiap 3 hari subjek dikontrol kesehatannya oleh peneliti dan bila terdapat keluhan dapat segera ditanggapi.

\section{Hasil dan Pembahasan}

Pada awal penelitian terdapat 10 penderita DM sebagai subjek dengan komposisi 8 orang $(42 \%)$ wanita dan 11 orang $(58 \%)$ laki-laki, semua subjek masih blam perawatan dokter. Dari subjek yang digunakan, 17 orang $(89 \%)$ mendapat oral antidiabetik (glibenklamid) sebanyak I tablet sehari; dan 2 orang ( $11 \%$ ) mendapatkan 1/2 tablet pagi dan 1 tablet siang. Pada akhir penelitian, jumlah subjek tinggal 10 orang sebab 9 orang mengundurkan diri dengan alasan sakit perut setelah minum yoghurt beberapa kali dan tidak suka minum yoghurt terus menerus karena rasa asam.

Dari hasil survei diit didapatkan bahwa semua subjek telah berusaha mengatur makanan sesuai dengan diit diabetes menurut nasehat dokter yang merawatnya terdahulu. Pola makan semuanya 2 kali makan sehari yaitu siang dan sore atau malam, sedangkan pada pagi hari hanya makanan kecil. Jenis dan komposisi makanan dapat dikatakan sudalı seimbang artinya hampir memenuhi syarat empat sehat, tetapi tidak ada yang biasa minum susu (Tabel 1).

Analisis kandungan zat gizi dari diit tersebut, didapatkan masukan zat gizi masih dalam batas anjuran, kecuali masukan lemak yang rendah (Tabel 2).

Penderita DM perlu mengatur jumlah masukan energi perhari. Total kebutuhan energi perhari yang dianjurkan dihitung berdasarkan diit seimbang yang artinya proporsional dalam komposisi dan jumlah total energi yang masuk seimbang dengan jumlah energi yang dikeluarkan. Jumlah energi yang dikeluarkan dihitung berdasarkan jenis kelamin, umur, dan aktivitas. Aktivilas semua subjek dihitung berdasarkan aktivitas teringan sampai sedang sehingga memerlukan energi perhari antara 1300 - 1500 Kalori (Martin et al., 1989). Untuk menyusun diit yang seimbang pada subjek ini disesuaikan dengan diit orang Indonesia pada umumnya yaitu mengandung karbohidrat $68-75 \%$, protein $12-15 \%$ dan lemak $10 \%$ dari total kebutuhan energi perhari (Asdie, 1987).

Pada perlakuan pemberian yoghurt sebagai makanan substitusi ada beberapa kendala yang harus diperhatikan atara lain 


\section{TABEL I, POLA DAN JENIS MAKANAN SUBJEK HASIL SURVEI DITT}

\begin{tabular}{ll}
\hline pola makan & $:$ sehari 2 kali, siang dan malam pagi hanya makanan kecil \\
makanan pokok & $:$ nasi \\
masakan sayuran & $:$ tumis/oseng-osengkacang, kangkung, bayem, sayur bening, kluban \\
& dan pecel \\
jenis lauk & daging, telur, hati, ikan, dan tempe \\
buah & : rombutan, pepaya, jeruk, pisang \\
nakanan selingan & $:$ air putil, syrop tropicana slim atau teh dengan pemanis. \\
minum &
\end{tabular}

TABEL 2. MASUKAN ZAT GIZI HASIL SURVEI DIIT AWAL DAN ANJURAN DIIT BAGI SUBJEK

\begin{tabular}{lcc}
\hline \hline zat gizi & rerata masukan & anjuran \\
\hline total energi & $1360,0 \pm 97,0 \mathrm{Kal}$ & $1300-1500 \mathrm{Kal}$ \\
karbohidrat & $1070,0 \pm 76,0 \mathrm{Kal}$ & $884-1162 \mathrm{Kal}$ \\
protein & $189,5 \pm 14,3 \mathrm{Kal}$ & $156-195 \mathrm{Kal}$ \\
lemak & $100,5 \pm 12,2 \mathrm{Kal}$ & $130 \mathrm{Kal}$ \\
kalsium & $353,0 \mathrm{mg}$ & $640,0 \mathrm{mg}$ \\
fosfor & $250,0 \mathrm{mg}$ & $640,0 \mathrm{mg}$ \\
besi & $24,0 \mathrm{mg}$ & $15,0 \mathrm{mg}$ \\
\hline
\end{tabular}

standarisasi kandungan zat gizinya dan penerimaan masyarakat di Indonesia yang belum semuanya terbiasa mengkonsumsi bahan makanan yang terbuat dari susu (dairy product). Secara pasti jenis susu yang digunakan sebagai bahan pembuat yoghurt tidak dapat diketahui karena ini merupakan rahasia perusaliaan. Pada umumnya, yoghurt dibuat dari susu rendah lemak (susu skim) ditambah starter Lactobacillus atau Yeast Kluyvermyces lactis atau Aspergilus niger. Bila ditinjau komposisi susu skim, ternyata kandungan lemaknya berkisar $0,1 \%$ dan kandungan zat gizi lainnya sama seperti pada susu sapi penuh (AAK, 1974; Suharto, 1979).
Pada pembuatan yoghurt, laktosa difermentasi menjadi asam laktat dan gas $\mathrm{CO}_{2}$, sehingga kadar laktosa menjadi rendah, sedangkan kadar zat gizi yang lain tidak berubah. Dengan demikian dikirakan bahwa minum yoghurt dalam jangka waktu relatif lama pada penderita DM, akan dapat menaikkan status gizi tanpa diikuti peningkatan kadar glukosa darah. Hal ini sangat menguntungkan bagi penderita DM sebab pada DM ada kecenderungan terjadi penurunan status gizi dan peningkatan kadar glukosa darah bila diitnya tidak diatur Jengan baik.

Hasil analisis komposisi yoghurt 
pada penelitian ini, didapatkan bahwa kadar laktosa dan lemaknya rendah (Tabel 3). Kandungan laktosa yang rendah ini disebabkan karena laktosa telah difermentasi menjadi asam laktat sehingga yoghurt tersebut mempunyai $\mathrm{pH}$ berkisar 6,1 dan rasanya asam. Rasa asam ini merugikan sebab beberapa subjek penelitian tidak tahan terhadap rasa asam tersebut. Dari segi lain, kadar laktosa yang rendah itu menguntungkan karena mencegah timbulnya gejala intoleransi laktosa (Paige et al., 1975). Hidrolisis 1 molekul laktosa di usus oleh laktase akan menghasilkan 1 molekul glukosa dan 1 molekul galaktosa, yang selanjutnya akan diabsorpsi oleh usus. Dengan demikian dapat dimengerti bila kadar laktosa di dalam makanan rendah maka glukosa dan galaktosa yang diabsorpsi hanya sedikit sehingga post parandial tidak terjadi kenaikkan kadar glukosa darah yang menyolok. Disamping itu, hidrolisis laktosa oleh laktase berlangsung lambat yaitu separoh dari kecepatan hidrolisis sukrosa (Martin et al,, 1989), ini berarti memberikan waktu agar glukosa dan galaktosa yang diabsorpsi itu dapat masuk ke dalam sel untuk dimetabolisir.

Berdasarkan analisis komposisi yoghurt didapatkan kandungan protein $4,3 \%$, lemak $0,3 \%$ dan laktosa $3,2 \%$ (tabel 3 ), herarti kandungan energi total dari $100 \mathrm{~g}$ yoghurt adalah $32 \mathrm{Kal}$ atau setara dengan $2,1 \%$ dari kebutuhan energi individu perhari. Kadar lemak yang rendah pada yoghurt itu menguntungkan sebab komsumsi yoghurt tidak menimbulkan kenaikan kadar lipid darah yang bermakna (Rosenweig et al., 1981).

Yoghurt yang diberikan kepada subjek merupakan makanan substitusi, maka dit subjek dalam perlakuan dikurangi jumlah karbohidratnya (nasi) sebanyak $8 \mathrm{~g}$ atau 32 Kal, sedangkan konsumsi sayuran diperbanyak. Dalam pemberian yoghurt lernyata ada keluhan terasa asam dan sebagian besar subjek belum terbiasa minum yoghurt sehingga ada beberapa subjek yang tidak dapat mengikuti penelitian sampai selesai.

Dari hasil survei diit didapatkan bahwa masukan energi total perhari pada awal penelitian $1360 \pm 97 \mathrm{Kal}$ dan pada akhir penelitian $1300 \pm 78 \mathrm{Kal}$ (Tabel 2 dan Tabel 3). Berdasarkan analisis statistik menunjukkan bahwa masukan energi pada awal dan akhir penelitian itu tidak berbeda bermakna $(P>0,05)$ dan masih dalam batas yang sesuai dengan anjuran. Suatu yang perlu diperhatikan bahwa masukan kalsium dan fosfor dari diit itu rendah sebab kalsium hanya terpenuli $55 \%$ dan fosfor terpenuhi $39 \%$ dari kebutuhan yang dianjurkan, tetapi pengaruhnya secara diagnosis fisik belum tampak. Sedangkan masukan zat besi cukup tinggi yaitu $I 60 \%$ dari kebutulan yang dianjurkan (Tabel 2).

Pada pemeriksan berat hadan yang dilakukan sebelum perlakuan, menggunakan perhitungan berat badan ideal berdasarkan rumus Brocca:

Berat badan $=($ tinggi badan -100$) \pm 10 \%$

didapatkan berat badan subjek rerata masih dalam batas normal yaitu $51,7 \pm 5,3 \mathrm{~kg}$; dengan tinggi badan rerata $161,3 \pm 4,5 \mathrm{~cm}$.

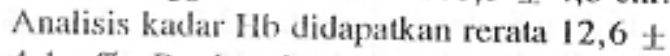
$4,1 \mathrm{~g} \%$. Berdasarkan surat edaran Menteri Kesehatan RI No. 7367/Menkes/XI/1989 bahwa batasan kadar $\mathrm{Hb}$ normal penduduk Indonesia dewasa untuk laki-laki $13 \mathrm{~g} \%$ dan untuk prempuan $12 \mathrm{~g} \%$. Subjek penelitian ini jumlah laki-laki dan perempuannya hampir berimbang maka disimpulkan bahwa rerata $\mathrm{Hb}$ yang didapatkan di atas masih dalam batas normal.

Setelah subjek mendapat perlakuan, diperoleh berat badan berkisar antara 49,0 - 69,0 kg dengan rerata $53,4 \pm 7,5 \mathrm{~kg}$. Apabila dibandingkan dengan berat badan awal ternyata ada kenaikan yang bermakna 
TABEL 3. KOMPOSISI YOGHURT DAN SUSU SKIM

\begin{tabular}{lll}
\hline \hline & Yoghurt & susu skim \\
\hline air & $81,7 \%$ & $90,5 \%$ \\
total solid & $18,3 \%$ & $9,5 \%$ \\
protein & $4,3 \%$ & $4,6 \%$ \\
lemak & $0,3 \%$ & $0,1 \%$ \\
laktosa & $3,2 \%$ & $4,8 \%$ \\
pH & 6,1 & 7,5 \\
\hline
\end{tabular}

TABEL 4. HASIL PEMERIKSAAN PRE-TEST DAN POST-TEST

\begin{tabular}{llll}
\hline \hline variabel & pre-test & post-test & uji-t \\
\hline berat badan $(\mathrm{kg})$ & $51,7 \pm 5,3$ & $53,4 \pm 7,5$ & $\mathrm{P}<0,05$ \\
tinggi badan $(\mathrm{cm})$ & $161,3 \pm 4,5$ & $161,0 \pm 4,6$ & $\mathrm{P}>0,05$ \\
kadar Hb $(\mathrm{g} \%)$ & $12,6 \pm 1,2$ & $13,2 \pm 2,0$ & $\mathrm{P}<0,05$ \\
$\begin{array}{l}\text { kadar glukosa } \\
\text { puasa (mg\%) }\end{array}$ & $159,0 \pm 46,3$ & $158,0 \pm 66,0$ & $\mathrm{P}>0,05$ \\
masukan energi (Kal) & $1360 \pm 97$ & $1300 \pm 78$ & $\mathrm{P}>0,05$ \\
\hline
\end{tabular}

(P<0,05). Analisis kadar Hb setelah perlakuan didapatkan kadar Hb berkisar 11,0 - $15,0 \mathrm{~g} \%$ dengan rerata $13,2 \pm 2,0 \mathrm{~g} \%$; dibandingkan dengan kadar $\mathrm{Hb}$ awal ternyata ada kenaikan yangbermakna $(P<0,05)$. Dari hasil ini disimpulkan bahwa status gizi penderita menjadi lebih baik, mungkin dapat diartikan bahwa lemak dan protein tubuh yang dibongkar untuk sumber energi akan cepat diganti oleh masukan dari diit. Disamping itu mungkin glukosa yang masuk ke dalam sel bertambah karena ada perbaikan status gizi sehingga oksidasi glukosa menghasilkan energi yang cukup tanpa harus disertai oksidasi asam lemak atau asam amino. Tentunya hal ini memerlukan pembuktian lebilı lanjut.
Sebelum subjek diberi perlakuan, rerata kadar glukosa darah puasa adalah $159,0 \pm 46,0 \mathrm{mg} \%$. Setelah minum $150 \mathrm{~g}$ yoghurt, pemeriksaan kadar glukosa darah pada menit ke 30 adalah 153,0 \pm 0 52,0 $\mathrm{mg} \%$, berarti ada kenaikan tetapi tidak bermakna $(P>0,05)$ dan pada menit ke 120 adalah $150,0 \pm 47,0 \mathrm{mg} \%$ berarti ada kenaikan bermakna $(P<0,05)$ (Tabel 5 dan gambar 1).

Setelah subjek diberi perlakuan, rerata kadar glukosa darah puasa adalah $158,0 \pm 66 \mathrm{mg} \%$; setelah minum yoghurt, pemeriksaan kadar glukosa darah pada menit ke 30 adalah $144,0 \pm 61 \mathrm{mg} \%$, berarti ada penurunan yang bermakna $(\mathrm{P}<0,05)$ dan pemeriksaan pada menit ke 
Buletin Peternakan Vol. 19, 1995

TABEL 5. KADAR GLUKOSA DARAH (mg\%) HASIL TES MINUM YOGHURT PADA PRETEST DAN POSTEST

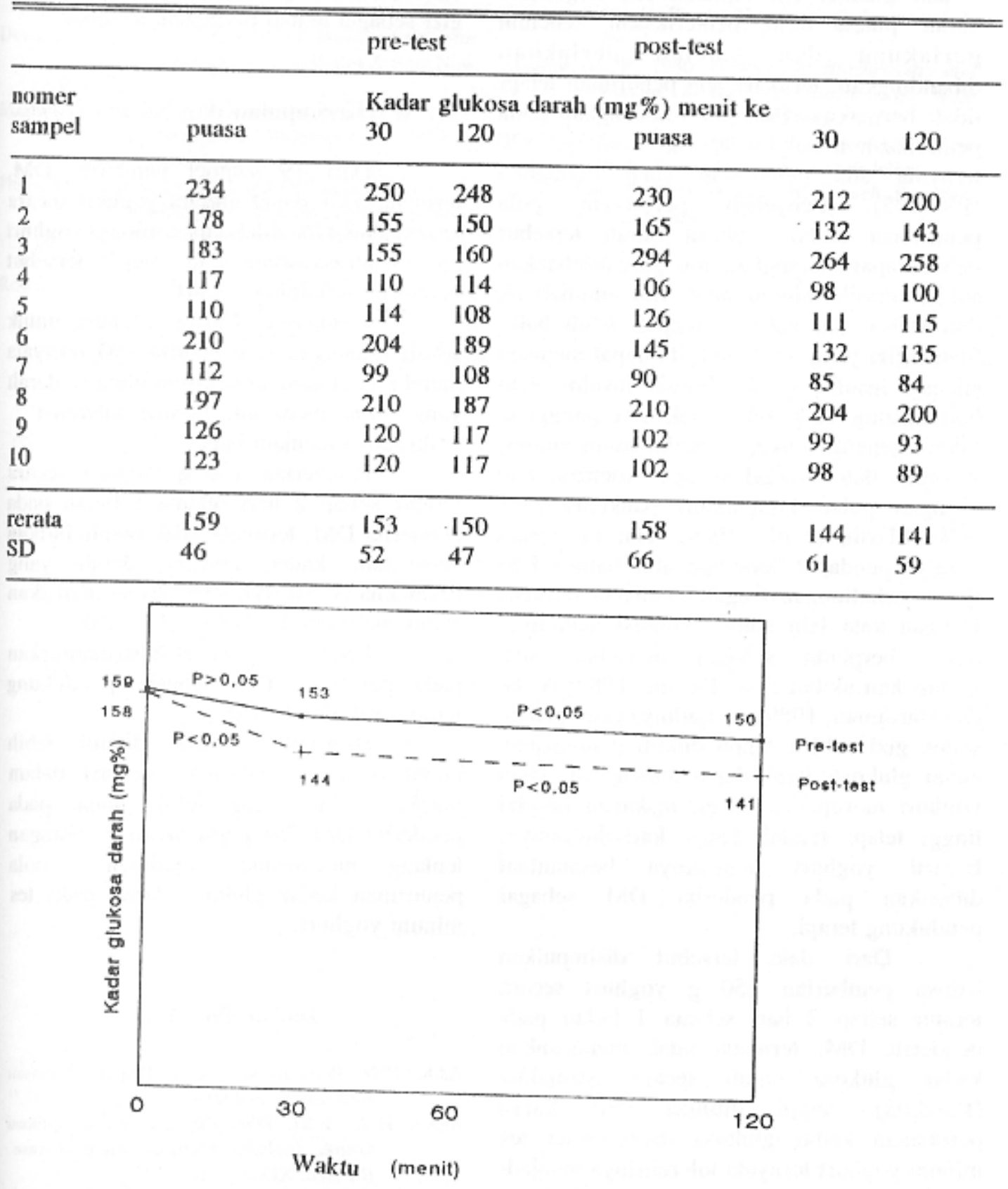

Gambar 1. Pola perubahan kadar glukosa darah hasil tes minum yoghurt 
120 adalah $141,0 \pm \mathrm{mg} \%$, berarti juga ada penurunan yang bermakna $(\mathrm{P}<0,05)$ (Tabel 5 dan gambar 1). Apabila kadar glukosa darah puasa lasil pemeriksaan sebelum perlakuan dan setelah perlakuan dibandingkan, ternyata ada penurunan tetapi lidak bermakna ( $P>0,05$ ). Sedangkan pada pemeriksan menit ke 30 dan menit ke 120 ternyata ada penurunan yang bermakna $(P<0,05)$. Penyebal perbedaan pola penurunan kadar glukosa darah tersebut belum dapat diterangkan, mungkin disebabkan subjek masih minum obat oral antidiabetik dan status gizi subjek menjadi lebilı baik. Status gizi yang lebih baik itu dapat memacu sintesis insulin sebab sintesis insulin akan berlangsung baik bila tidak ada gangguan faktor genetik, cukup tersedia asam amino, vitamin, dan mineral sebagai koenzim dan jaringan pulau Langerhans pankreas yang baik (Martin et al., 1989). Hal ini sesuai dengan pendapat beberapa ahıli bahwa DM dapat berhubungan dengan kondisi malnutrisi. Dengan kata lain bahwa kondisi malnutrisi dapat berperan sebagai penyebab atau merupakan akibat DM (Devlin, 1982; Asdie dan Hardiman, 1989). Terjadinya peningkatan status gizi subjek tanpa diikuti peningkatan kadar glukosa darah dapat dimengerti sebab yoghurt merupakan balıan makaman bergizi tinggi tetapi rendah kadar karbohidratnya. Berarti yoghurt tampaknya bermanfaat diberikan pada penderita DM selagai pendukung terapi.

Dari data tersebut disimpulkan bahwa pemberian $150 \mathrm{~g}$ yoghurt secara teratur setiap 2 hari selama 1 bulan pada penderita DM, ternyata tidak menurunkan kadar glukosa darah secara bermakna $(\mathrm{P}>0,05)$, tetapi ditinjau dari kurva perubahan kadar glukosa daralı pada tes minum yoghurt ternyata toleransinya menjadi lebih baik, artinya kadar glukosa darah pemeriksaan 2 jam post- parandial ternyata menurun bermakna $(\mathrm{P}<0,05)$. Disamping itu, ditinjau dari analisis berat badan dan kadar Hb ternyata ada kenaikan yang bermakna $(\mathrm{P}<0,05)$, artinya terdapat perbaikan status gizi sebagai akibat perlakuan tersebut.

\section{Kesimpulan dan Saran}

Dari 19 sampel penderita DM, ternyata $53 \%$ dapat minum yoghurt secara teratur dan $47 \%$ tidak tahan minum yoghurt karena terasa asam dan subjek tersebut belum biasa minum yogurt.

Pemberian $150 \mathrm{~g}$ yoghurt untuk sekali niinum pada penderita DM ternyata memberikan gambaran kurva glukosa darah yang terus menurun, berarti toleransi ghukosanya menjadi baik.

Pemberian $150 \mathrm{~g}$ yoghurt secara teratur setiap 2 hari selama 1 bulan pada penderita DM, ternyata tidak menimbulkan perubahan kadar glukosa darah yang bermakna ( $P>0,05)$, tetapi dapat menaikan status gizi yang bermakna $(P<0,05)$.

Pemberian yoghurt dapat dianjurkan pada penderita DM sebagai pendukung terapi oral antidiahetik.

Disarankan untuk diteliti lebih lanjut dengan pemberian yoghurt dalam jangka waktu yang lebih lama pada penderita DM dan perlu dicari keterangan tentang mekanisme terjadinya pola penurunan kadar glukosa darah pada tes minum yoghurt.

\section{Daftar Pustaka}

AAK, 1974. Beternak sapi perah. P'acrhit Yayusan Kanisius Yogyakarta.

Asdie, H.A. 1987. Hiperglikemin dun kompliknsi kranik Disbetes Mellitus orang dewasa. B.I.Ked. XIX(4): 118 - 133 ,

Asdic, H.A. 1990, Genctika Dinbetes Mellitus. B.I.Ked. XXII(2): $498-58$.

Asdic, H.A dun Hardiman, D, 1989. Putogenesis 
Diabetes Mellitus tidak tergantung insulin. B.I.Ked. XXI(3): $91-97$.

Depkes R.I. 198I. Daflar komposisi bahan makanan. 1981. diterbitknn oleh Direktorat gizi Depkes RI. Jukurta.

Devlin, T.M. 1982. Textbook of Biochemisiry with clinical correlations. Julu Willey \& Sons New York.

Martin, D.W., Mayes, P.A and Rodwell, N.W. 1989. Harper's Review of Biochemistry. 201h eds. Lange Maruzen Asia

Paige, D.M., Buyless, T.M nnd Dellinger, W.S. 1975. Relationship of milk consumption to blood glusose rise in infolernnce individunls. Am, J. C1in. Nutr. 28: 677 - 680.

Rosenweig, N.S., Burger, E. M., Vyner, P.D and Ferreire J.J. 1981. The effect of skim milk, yoghurt and full cream milk on human serum lipids. Am. J. Clin. Nutr. 34: 351 - 354.
Stryer, L. 1988. Biochemistry. 3th. eds, W.H. Frecman and Company New York.

Suharto. 1979. Masalah produksi susu dan peranan sust schngai sumber gizi manusia. Wartn Pergizi Pangan Cabang Yogynkarta, Vol. $l$. No. 1

Talwar, G. P. 1980. Textbook of Biochemistry and Haman Biology, Prentice-hill of Indin Private Limited New Dellii.

Tiezt. N.W. 1986. Textbook of Clinical Chemistry. W.B. Suunders Company Philudelhia.

WHO. 1985. Diahetes Mellitus. WHO Tech. Rep. Ser. 310. Geneve. 